San Jose State University

SJSU ScholarWorks

Master's Theses

Master's Theses and Graduate Research

Spring 2011

\title{
Problem solving with geographic networks in the Sacramento-San Joaquin Delta
}

Steven Hong

San Jose State University

Follow this and additional works at: https://scholarworks.sjsu.edu/etd_theses

\section{Recommended Citation}

Hong, Steven, "Problem solving with geographic networks in the Sacramento-San Joaquin Delta" (2011). Master's Theses. 3932.

DOI: https://doi.org/10.31979/etd.psw4-dhmv

https://scholarworks.sjsu.edu/etd_theses/3932

This Thesis is brought to you for free and open access by the Master's Theses and Graduate Research at SJSU ScholarWorks. It has been accepted for inclusion in Master's Theses by an authorized administrator of SJSU ScholarWorks. For more information, please contact scholarworks@sjsu.edu. 


\title{
PROBLEM SOLVING WITH GEOGRAPHIC NETWORKS
}

IN THE SACRAMENTO-SAN JOAQUIN DELTA

\author{
A Thesis \\ Presented to \\ The Faculty of the Department of Geography \\ San Jose State University \\ In Partial Fulfillment \\ of the Requirements for the Degree \\ Master of Arts
}

by

Steven Prasert Hong

May 2011 
(C) 2011

Steven Prasert Hong

ALL RIGHTS RESERVED 
The Designated Thesis Committee Approves the Thesis Titled

PROBLEM SOLVING WITH GEOGRAPHIC NETWORKS

IN THE SACRAMENTO-SAN JOAQUIN DELTA

by

Steven Prasert Hong

APPROVED FOR THE DEPARTMENT OF GEOGRAPHY

SAN JOSE STATE UNIVERSITY

May 2011

Dr. M. Kathryn Davis

Dr. Richard Taketa

Jeremy Lukins
Department of Geography

Department of Geography

San Francisco Public Utilities Commission 


\section{ABSTRACT \\ PROBLEM SOLVING WITH GEOGRAPHIC NETWORKS \\ IN THE SACRAMENTO-SAN JOAQUIN DELTA}

\section{By Steven Prasert Hong}

The Sacramento-San Joaquin Delta (Delta) serves as the crossroads for many geographic networks that crisscross California. These include a conveyance network for drinking water, a biological network for delta smelt, and a transportation network for roads. As a result, local Delta issues concerning flooding and endangered fish hold implications for the entire state. This thesis explores these underlying network structures that pass through the Delta as a means for solving subsets of these most difficult challenges.

Recognition of these larger networks enable the transformation of the Delta's convoluted maze of waterways and islands into a series of nodes and segments. Network principles of backup routes, shortest paths, and busiest intersections are applied to uniquely Delta problems resulting in lists for potentially stranded islands, optimal monitoring sites for delta smelt, and select paths for levee fortification. This thesis concludes that networks can be a versatile tool not only for the Delta but wherever networks exist. Especially with increasing clashes between people and nature, networks offer a way to connect seemingly disparate problems with solutions in the form of specific locations that establishes the starting point for stakeholders to work towards a compromise. 


\section{ACKNOWLEDGEMENTS}

This thesis represents the completion of a long journey. I thank Dr. Kathryn Davis, Dr. Richard Taketa, and Jeremy Lukins for modeling the creativity, passion, and professionalism that cannot be found in any book. I thank my son, Seth, for reminding me of the curiosity that first led me to geography as a boy. Above all, I thank Makiko to whom I dedicate this thesis. We took participating in each other's lives to the extreme by going back to school together. I will always characterize my days at San Jose State by the time I spent with her. 


\section{TABLE OF CONTENTS}

CHAPTER 1: INTRODUCTION 1

CHAPTER 2: KINDS OF NETWORK ANALYSIS 17

CHAPTER 3: NETWORK PROBLEM SOLVING DEMONSTRATION 23

Example 1: Stranded Islands $\quad 25$

Example 2: Optimal Monitoring Sites 31

Example 3: Drinking Water Paths 38

CHAPTER 4: CONCLUSION 41

REFERENCES 


\section{LIST OF FIGURES}

1-1 Depiction of Euler's seven bridges 3

1-2 Urbanization in Discovery Bay $\quad 6$

1-3 Map of the Sacramento-San Joaquin Delta 7

1-4 Peat moss levees and island subsidence $\quad 8$

1-5 Jones Tract levee breach in 2004

1-6 Delta smelt 13

3-1 The Delta islands and waterways used for the study area 24

3-2 Converting from roads to centroids connection display 27

3-3 Potential stranded islands $\quad 28$

3-4 Constructed delta smelt network 32

3-5 Optimal monitoring sites for delta smelt 35

3-6 Comparing proximity to current Department of Fish and Game’s survey sites 37

4-7 Shortest drinking water paths 39

Note: Figures are the work of the author unless otherwise indicated in the caption. 


\section{LIST OF TABLES}

2-1 Sample network using the binary connectivity matrix

3-1 Summary of potential stranded islands and possible solutions

3-2 Top ten "From” connections

3-3 Top ten “To” connections

Note: Tables are the work of the author unless otherwise indicated in the caption. 


\section{Chapter 1}

\section{Introduction}

The Sacramento-San Joaquin Delta (Delta) is at the intersection of the Sacramento and San Joaquin Rivers in Northern California. The water passing through the Delta provides drinking water to two-thirds of California's population (Mount and Twiss 2005) and irrigation water to its $\$ 30$ billion dollar agricultural industry (California Energy Commission 2008). At the same time, this water simultaneously supports fish and wildlife in the region's ecosystem. However, the deterioration of the levees that protect the Delta's fresh water and diminishing fish populations point toward a collapse of the system. These problems have been known for years, even decades, but now the conditions are reaching a critical point. Consequences include potential flooding, farm fields left unplanted, mandatory water restrictions, and possible extinction of fish species including the delta smelt. Despite the bleak outlook, the state lacks an agreement on action; rather, the process continues to call for more debate and studies in search of a single holistic solution.

An example is the most recent scientific effort to have specialists from different fields decide how much fresh water is needed to keep the Delta ecosystem healthy (Simitian 2009). The remaining water supply would then be divided for other uses such as drinking and agriculture. However, even if agreement on water allocations can be reached among the scientists, basing decisions on portioning the water supply presents several problems. First, the water supply is variable depending on the snow pack. Second, water usage is also variable. This pertains to people as well as wildlife. In the 
case of fishes, different amounts of fresh water may be needed depending on their stage of life. Third, it does not deal with prominent problems that do not depend directly on the share of the water supply. This thesis addresses this third issue as water supply allocations do not directly affect fish entrainment or flooding.

Although the current problem-solving approach has focused on the commonality that these problems have with water, the approach of this thesis focuses on the commonality that they have in location. The Delta sits at the crossroads of many geographic systems, or networks, that reach other regions of the state. The conveyance of fresh water through the Delta provides irrigation to agricultural interests in the Central Valley and drinking water to urban centers as far as Southern California. The Delta roadways link the urban centers of Sacramento and the San Francisco Bay Area. The Delta also provides a conduit for migratory fish species, such as the Chinook salmon and the delta smelt, that travel between the fresh water found inland and the saltier waters of the San Francisco Bay. These greater networks that pass through the Delta elevate its importance from a local concern to a state concern.

At its core, a network is an arrangement of nodes and edges that offers an alternative view of the world by simplifying its complexities. One of the earliest recorded uses of networks was to answer a question posed by Leonhard Euler. In $18^{\text {th }}$ century Prussia, the town of Konigsberg (present day Kaliningrad, Russia) was divided by the Pregel River. Within the river were two islands connected to each other and the mainland. Euler wanted to know if he could cross all seven bridges in the town without crossing the same bridge more than once (see Figure 1-1). By equating the land and bridges 
graphically to a connected network of nodes and edges, what appeared to be a difficult problem now became very solvable. This network supplied the underlying pattern needed on which to base his calculations to ultimately conclude that crossing the same bridge only once was not possible (Watts 2003).

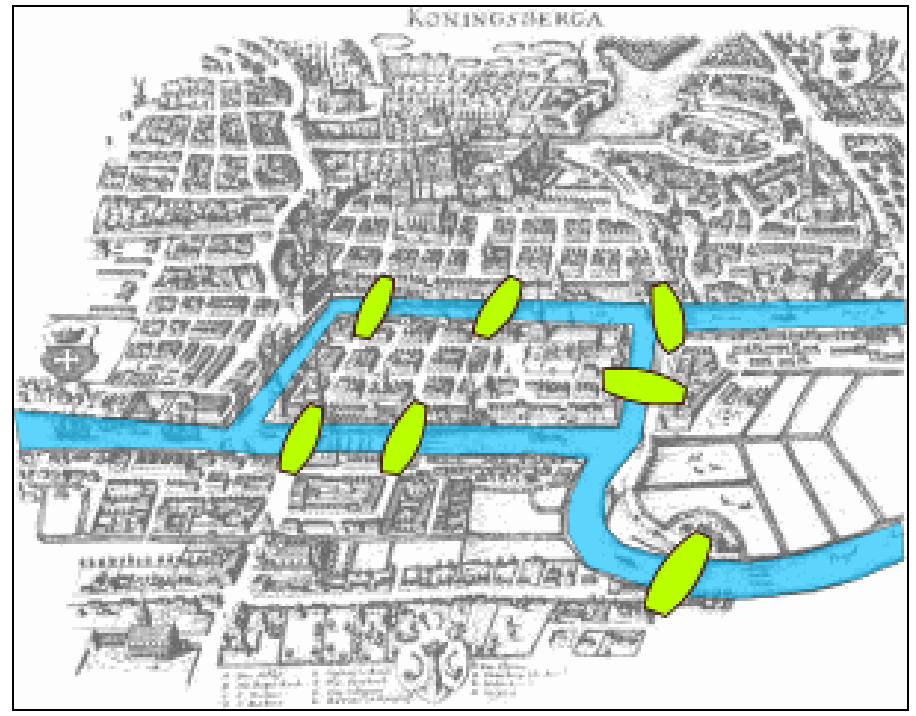

Figure 1-1: Depiction of Euler's seven bridges.

Note: From Wikipedia. Reprinted with permission from Bogdan Giusca.

By focusing on the structure, networks offer two advantages. First, as with cases as complex as the Delta, networks can serve as data filters. Society calls on government to conduct thorough investigations to understand the short-term and long-term impacts. With data being collected for every potential factor regardless of how big or small, not only is the data collection time consuming, but the daunting task of integrating all these into a larger picture becomes more and more difficult with each additional dataset. Gladwell (2005) wrote that being overwhelmed by data hinders the human ability to make decisions quickly. In the case of the Delta, years and decades have passed and still there is still not enough time to process the data. Second, because the focus is on the 
network structure, one can conceivably compare networks of completely different forms. In other words, one could compare the network structures of seemingly unrelated fields such as electric power grids, railroads, and the Internet. Furthermore, tools and measures developed from other fields may be applicable as well. Contributions from unlikely fields studying networks include ecology, sociology, and physics (Watts 2003; Termorshuizen, Opdam, and van den Brink 2007). With the presence of networks in the Delta such as water, roads, and fish, analysis of their structure may help contribute to solutions in the Delta. Therefore, this thesis explores the problem-solving implications of viewing the Delta as the crossroads of a series of networks.

Many of the Delta's current problems are rooted in its history. With the Arkansas Act of 1850, the federal government ceded swamplands to states to encourage their reclamation. This started the Delta reclamation period from 1850 to 1940 . The Delta swamplands consisted of many individual islands of peat moss that California sold at \$1 per acre. Most of the perimeter areas were the first to be reclaimed as they were easier to drain. The fastest and cheapest way to drain these islands was to push the peat moss from the interior to form the outer walls of the levees before pumping out the water. Many Chinese laborers were hired to do this manual work. From 1880 to the early 1900's, the introduction of heavy equipment into the Delta made reclamation of even the central islands possible. In a similar process, the peat moss material was dredged from the interior of the islands, and the spoils were used to build up the levees. This peat moss was highly fertile and quickly made the region an agricultural center known for asparagus, 
Bartlett pears, corn, and other crops (Lund, Hanak, Feenor, Howitt, Mount, and Moyle 2007; Hundley 2001).

In the late 1930's, the federal government funded the Central Valley Project (CVP) to bring water through the Delta to areas further south for additional agricultural expansion. The state later followed in 1957 with the State Water Project (SWP) to support urban growth, especially in Southern California. Water from the Sacramento River is released by the Shasta, Keswick, and Oroville Dams. Water from the San Joaquin River comes primarily from its tributaries of the Tuolumne, Merced, and Stanislaus Rivers as the San Joaquin River's main artery upstream mostly is diverted to the Central Valley by the Friant Dam. Once reaching the Delta, the flow from the Sacramento and San Joaquin creates a fresh water barrier that makes its way from the north to the south end of the Delta. During the process, a significant portion of fresh water also escapes through the San Francisco Bay as outflow and benefits much of the native marine ecosystem. The fresh water that reaches the southern end is captured by two massive pumps, called the Banks Pump under the SWP and the Tracy Pump under the CVP, and sent further south. Some of the SWP water is diverted to Alameda and Santa Clara Counties via the South Bay Aqueduct. Some of the CVP water goes to Santa Clara County through the San Felipe Project, while some is diverted through Fresno and onto Bakersfield before reconnecting with the San Joaquin River. However, the majority of the CVP and SWP water continues southward before meeting at the California Aqueduct and goes on to service the Southern California metropolitan areas (Lund et al. 2007; Hundley 2001). 
Both the SWP and CVP were highly successful in their mission. Agriculture became a multibillion dollar industry. Population across the state has risen. The state estimates that the population will reach 45 million by 2025 and 90 million by 2100 (Lund et al. 2007). The Delta’s proximity to the urban areas of the San Francisco Bay Area and the Sacramento metropolitan areas also fueled urbanization in the region. The popularity of cities on the Delta periphery such as Pittsburg, Antioch, and Stockton has pushed new housing developments such as Discovery Bay (see Figure 1-2) further into the Delta’s interior. Workers flocked to this region to find affordable housing and enjoy outdoor recreation such as boating, fishing, and hunting. Various communities have had as many as 130,000 homes in the planning stage (Dreifus 2006). However, all this development has placed considerable pressure on the peat moss levees that go way beyond their original agricultural purposes.

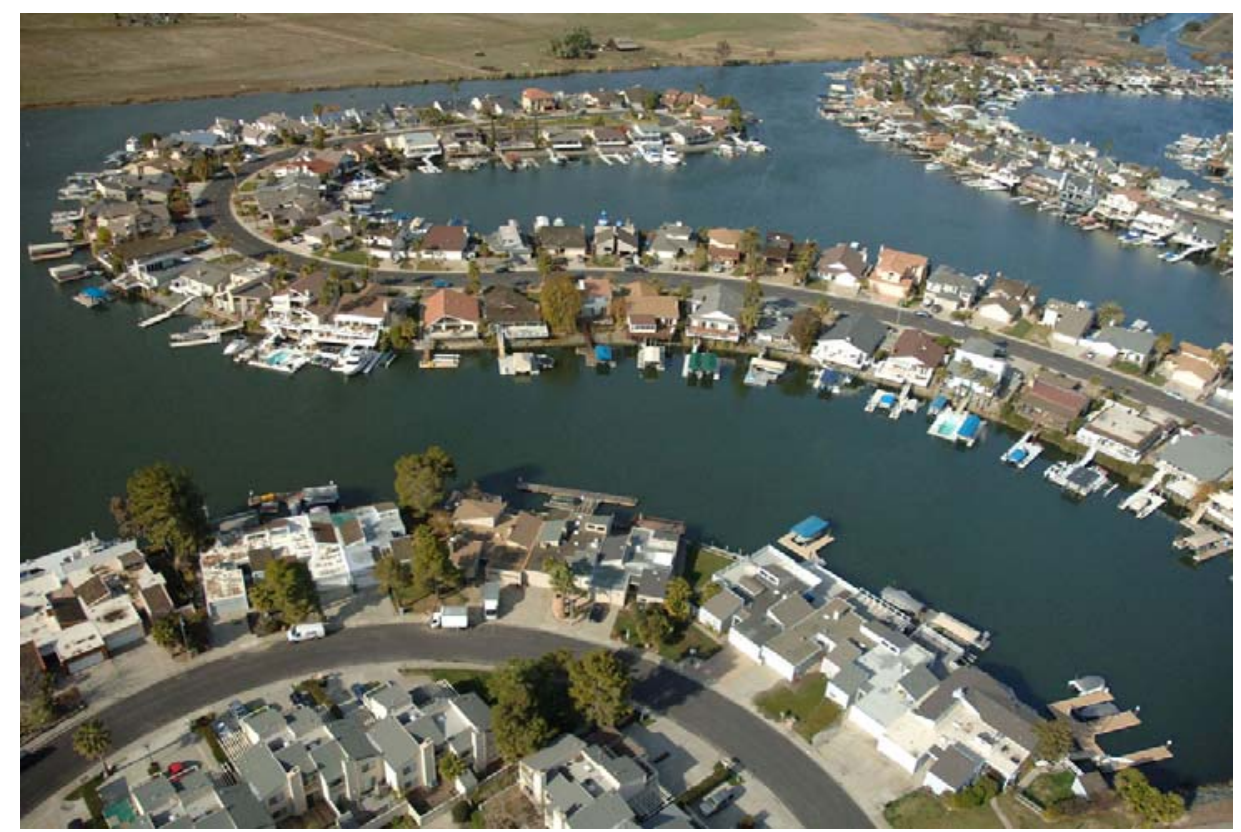

Figure 1-2: Urbanization in Discovery Bay. Note: From the Department of Water Resources. 


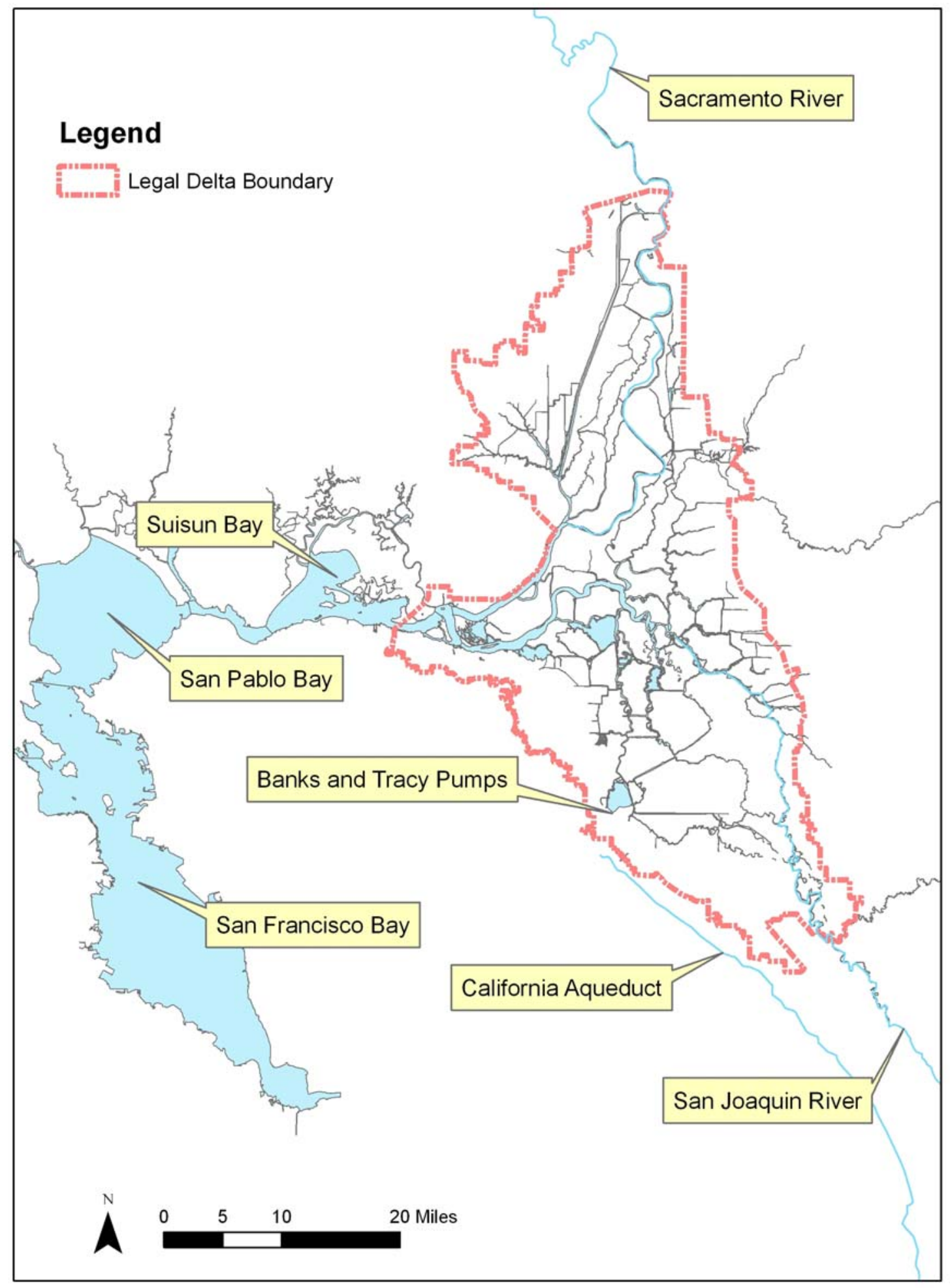

Figure 1-3: Map of the Sacramento-San Joaquin Delta. 
When exposed to air, peat moss oxidizes and begins to dissipate. This causes the levees to weaken and an island's interior to sink, or subside, over time. Especially with farming practices that till the soil in the interior of an island, the oxidation process quickens and increases subsidence creating bowl shaped islands below sea level over a period of years (see Figure 1-4).
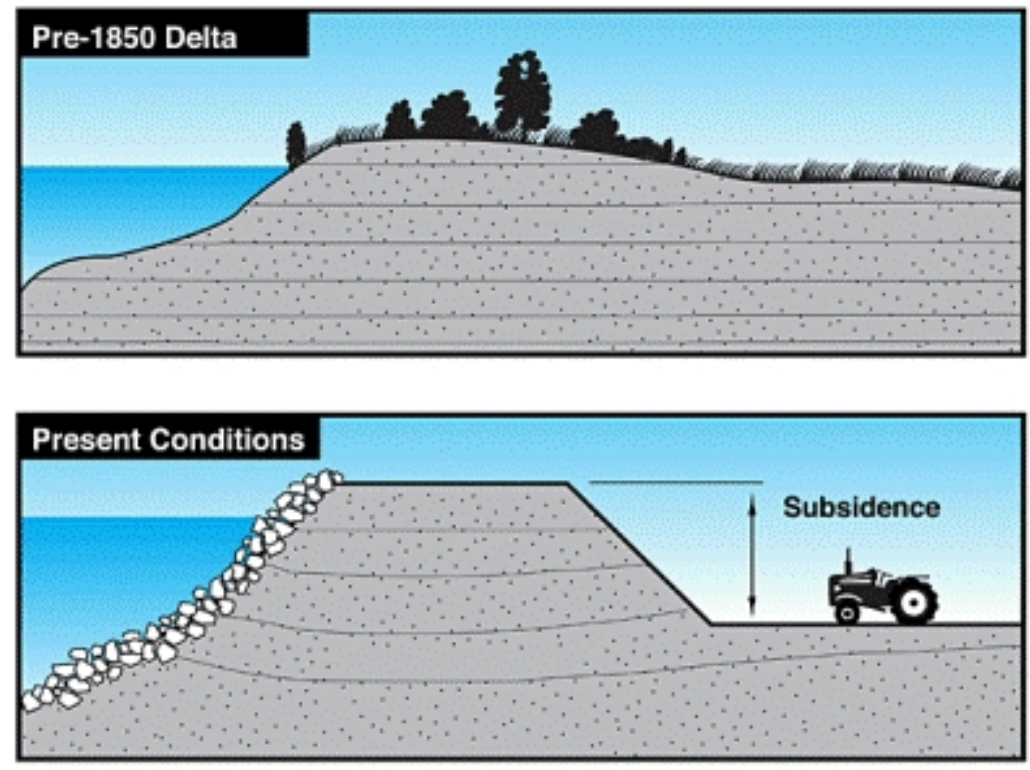

Figure 1-4: Peat moss levees and island subsidence. Note: From the Department of Water Resources.

When Hurricane Katrina struck the New Orleans area in 2005, the levees failed to protect the city from flooding. Images of the devastation prompted many to wonder whether the Sacramento-San Joaquin Delta region was next. There were some obvious comparisons. The city of New Orleans was built on the Mississippi Delta peat moss and suffered from below sea level subsidence that relied on its levees for protection (van Heerden and Bryan 2006). However, in many respects, the levees in the Sacramento-San Joaquin Delta are in a worse state. Although a combination of factors including faulty 
levee construction ultimately led to the New Orleans disaster, the levees were designated at a 200-year flood protection. These steel and concrete levees failed because they sat on soft peat moss foundation. The Delta levees are designated only at a 100 -year flood protection. In addition to the soft peat moss foundation, the Delta levees are made of the organic peat moss, so they naturally weaken over time through erosion and oxidation. This weakness allowed beavers burrowing into the levees to cause the 2004 Jones Tract flood (Tolan 2009); a beaver could not have caused the New Orleans flood. Furthermore, Mount and Twiss (2005) argue that heavy subsidence of the islands has left these levees more vulnerable than previously thought. A majority of the Delta islands are below sea level, some by as much as 25 feet. The resulting bowl-shaped characteristic of each of the islands further erodes the base of the levee from the landward side. Mount and Twiss' introduction of a levee force index factoring in the status quo rate of subsidence, erosion, rising sea level, and lack of maintenance showed that the levees were not up to their official 100-year flood protection ratings. They also calculated the probability of a large earthquake or storm rupturing levees within the next 50 years at an alarming 64 percent. If several levees were to fail, entire islands would flood resulting in agricultural losses, as well as massive salinity flows from the San Francisco Bay that would contaminate drinking water for a year or longer in what has been called the "Big Gulp” scenario (Dreifus 2006).

In addition, the funding needed to shore up the levees is severely lacking. The principal government agency responsible is the Department of Water Resources (DWR). At times this state agency collaborates with federal agencies such as the US Army Corps 
of Engineers and the U.S. Fish and Wildlife on federal levees and other related federalfunded projects. However, the majority of levee maintenance occurs under the DWR's Delta Levees Program. Of the 1100 miles of levees in the greater Delta region, the DWR manages about one-third of them directly and the other two-thirds indirectly through local districts. The Delta Levees Program, originally known as the "Way Bill” program, has been around since the 1970 's. One of the original principles was to split $50 \%$ of maintenance costs with the local districts for non-project levees. The passage of Proposition 13 in 1978 limited property tax increases on existing homeowners creating difficulty in the decades that followed for local districts to keep up with their side of the funding. In 2002, the court in Arreola v. Monterey County found the State responsible for any flood damages from state-maintained levees even where it was not the original builder, placing California at greater financial risk. Some estimates suggest an investment of $\$ 2$ billion is needed just to bring the existing levees up to the 100-year flood protection code. Over 140 levees have flooded since 1900 (California Department of Water Resources 2005). Although frequency has diminished in the recent decades of the program's existence, the damage has been more spectacular. The previously mentioned 2004 levee break on Jones Tract produced estimated losses of \$100 million mostly in agriculture, and suspended drinking water pumping to Southern California for several days. Only emergency reservoir releases prevented a complete shut down of drinking water. Now that these agricultural levees are being called on to protect increasing urban interests, the complexity of what is at stake has also increased (Lund et al 2007; California Department of Water Resources, 2005, 2007). 


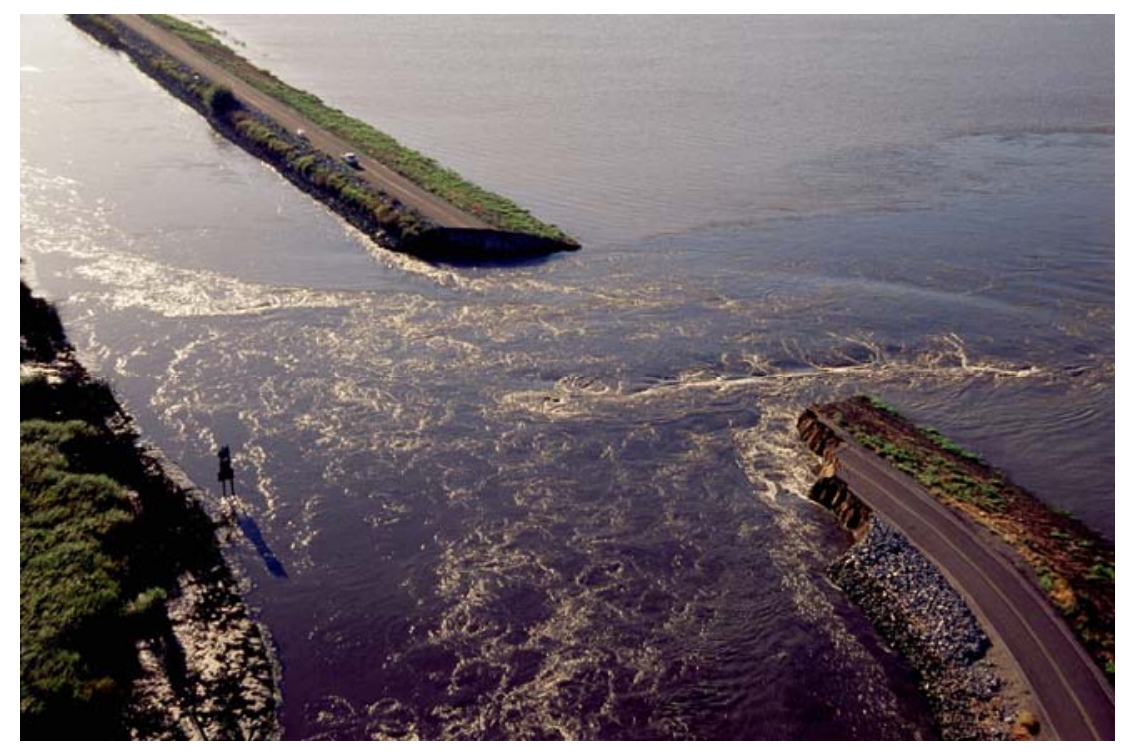

Figure 1-5: Jones Tract levee breach in 2004. Note: From the Department of Water Resources.

Continued human development has also had an impact on the fish population including the Chinook salmon, longfin smelt, and white and green sturgeon. However, the greatest controversy has followed the delta smelt. This two-inch silvery fish, once one of the most abundant species in the Delta, has seen its population numbers crash in recent years. Although entire populations of fish in general are not estimated, the number of delta smelt is believed to be only one tenth of the 2003 level. The U.S. Fish and Wildlife Service warned of a 50\% likelihood the species will go extinct in the next 20 years. It has been on the federal threatened species list since 1993 and there has been much talk of putting it on the federal endangered species list. Regardless of whether it is threatened or endangered, under the Endangered Species Act, one can not touch, harass, or kill a threatened or endangered species without a permit (U.S. Fish and Wildlife Service 2010). 
The delta smelt have been known to spawn in both the San Joaquin and Sacramento Rivers from March to May. Although these rivers are fresh, the smelt can live in brackish water and will do so as they pursue cooler temperatures and food sources. By late spring/early summer, the smelt are already beginning to move through the Delta. During this development stage, they face many threats including entrainment by the Banks and Tracy Pumps, where the pump literally sucks up the fish. In addition, they are vulnerable to predators and pesticides and must have an abundant source of phytoplankton for food. By mid-summer, the Delta reaches lethal water temperatures, and the smelt continue their migration to cooler Suisun Bay and eventually to San Pablo Bay. Adults swimming back to the Sacramento River cross the Delta in the winter. As the fish typically lives one year (sometimes two), the population depends on the survival of the previous year to fuel the population for the following year. Although there is still debate as to the major factor in the smelt's decline, pump entrainment clearly contributes to the diminishing population. The evidence can be found at the Banks and Tracy Pump stations where delta smelt has been identified among the entrained fish. Evoking the Endangered Species Act, the courts sided with the environmentalists in 2006 ordering that the pumps be kept idle until the migratory smelt had moved past. Subsequent years have also seen routine periodic closures of the pumps to allow the majority of smelt to pass (Bennett 2005; Lund et al. 2007; California Department of Fish and Game 2009). 


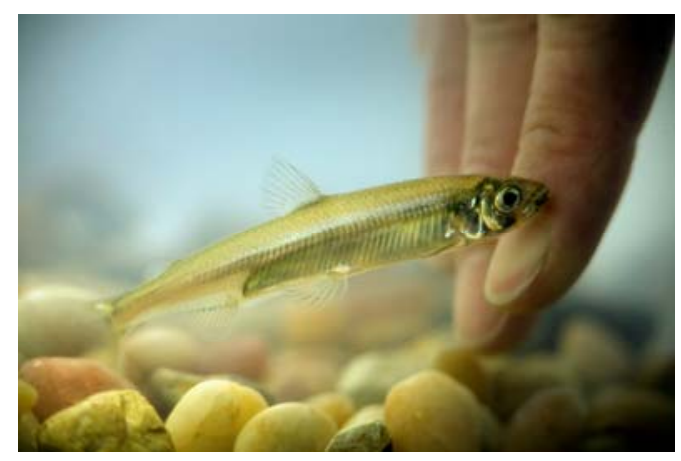

Figure 1-6: Delta smelt.

Note: From the Department of Water Resources.

The clash between people and nature also reflected the changing political climate.

For most of U.S. history, the land was looked upon as a natural resource to be tamed, especially in the West. Much of the West, including the Delta, was part of an iron triangle consisting of development agencies, politicians and beneficiaries which lasted from the 1920's to the 1950's. Prominent development agencies such as the Bureau of Reclamation, the Army Corp of Engineers, and municipal water agencies held sway over a society that placed emphasis on economic development and progress over ecological concerns. The latter half of the $20^{\text {th }}$ Century brought the first environmental laws that reversed this trend. The Clean Air Bill of 1963 was significant for enabling private citizens to file lawsuits. This continued with the previously mentioned Endangered Species Act of 1973 and its later amendments which sought to save endangered species from the path of development. These laws provided the legal strength to halt many massive civil engineering projects around the country that previously would have gone unimpeded (Hundley 2001).

This rise in environmentalism coincided with political battles in the Delta. Awareness of the harmful impact to the environment and a decrease in water quality led 
to the controversial peripheral canal ballot measure of 1982. The aim of the canal was to have drinking water bypass the Delta. Proponents argued the canal would protect drinking water from rising salinity and lead to environmental benefits by decoupling the uses. However, opponents, including many environmental groups, believed it would be a detriment to the environment by diverting too much water needed by the Delta's ecosystem for other uses. Environmentalists banded with farmers and many Northern Californians who saw this as a Southern Californian water grab to defeat the bill in a bitterly divided election (Lund et al. 2007).

In the aftermath of the defeat of the peripheral canal, the formation of the CALFED Bay Delta Program, or CALFED, in 1994 attempted to get both private and public stakeholders all together to work out their differences. Water municipalities, housing developers, residents, local government, commercial and recreational fishing and boating interests, and farmers all came together but failed to reach any significant agreements. Then, the flooding in New Orleans caused by Hurricane Katrina in 2005 occurred. This brought renewed calls to prioritize the immediate needs of people over the environment which angered many environmentalists, and led to the court order the following year to cease Delta pumping during delta smelt migration. By 2006, CALFED was for all intents and purposes dissolved as funding from key stakeholders, unhappy with the lack of resolution, was withdrawn (Lund et al. 2007).

The dissolution of CALFED paved the way for the latest effort to fix the Delta. In December 2009, the approval of four water reform bills (Water Bill) was touted as the solution. The highlights of the Water Bill include setting the environment and drinking 
water as coequal goals and assembling a Delta Stewardship Council to streamline decisions (California Department of Water Resources 2009). However, the absence of specific actions to specific problems places pressure on studies such as the previously mentioned water allocation plan to deliver unrealistic expectations. Furthermore, although passed, the Water Bill continues to be in danger of falling apart as the $\$ 11.4$ billion bond measure for funding is dependent on future voter approval. Fear of weak voter support has postponed the funding portion for at least two years (Buchanan 2010).

To overcome the decades of paralysis, an elegant solution is needed to deal with many of the Delta's complex elements simultaneously. While networks cannot solve all problems, they can address subsets of the larger flooding and delta smelt entrainment issues plaguing the Delta. Knowing the location of the smelt becomes very important to prevent entrainment, especially as they approach the Banks and Tracy Pumps. This not only saves the lives of delta smelt, but allows the pumps to be idle for the least amount of time. Thus, the problem of choosing optimal monitoring sites for that advanced warning becomes very pertinent.

The threats of flood come in different forms. There is the immediate danger to lives, but a related subset is identifying potential stranded islands in the Delta. This can occur when a neighboring island is flooded and becomes a barrier that prevents residents from reaching the mainland. A neighboring island with few residents would not likely have reinforced levees, while an island with urbanization would. This scenario needs to be considered as the pressure for urbanization grows while the prospect of reinforcing all the levees in the study area becomes an unaffordable option. Another threat from 
flooding is the possible contamination of the drinking water with salt water. As the 2004 flooding of Jones Tract illustrated, the Delta Island levees need to be upgraded and maintained. Rather than upgrading all of the levees, choosing select paths for water conveyance could ease the cost burden through a tunnel or armored aqueduct over the long term. A variety of solutions will be proposed to demonstrate the versatile range of networks by addressing these issues of optimal monitoring sites, stranded islands, and drinking water paths. 


\section{Chapter 2}

\section{Kinds of Network Analysis}

Network analysis can be conducted by physical or topological methods. A physical network analysis involves anything to do with its physical presence including measuring the segment distance between two nodes in kilometers or miles. In a topological network analysis, physical distance between nodes is not as important as the conceptual connection between them. In this case, rather than kilometers or miles, distance could be the degrees of separation between two people as in a social network.

An example of a physical network analysis is deciphering the rise of the Inca Empire. From 1400 until the Spanish arrival in 1532, the Inca Empire embarked on an expansion from the Cuzco region to encompass most of Peru and portions of Argentina, Ecuador, Bolivia, and Chile. The Inca acquired territory through a combination of kinship ties and military conquests. Considering the territorial boundaries, historians faced the quandary of how the Inca were able to integrate and hold captured territories despite a lack of people and resources. Smith (2005) provided a physical network analysis of the Inca road network by offering the view that ancient peoples such as the Inca did not look upon their empire in terms of territorial boundaries, but rather through a network of nodes and corridors. She surmised that the Inca did not need to protect its boundaries with an overwhelming presence by noticing the road network coincided with the reaches of the empire expansion. Instead, ruling through the road network allowed for the rapid shuttling of resources or troops wherever needed. 
The road network not only offers an explanation for the empire's rapid growth but might also offer insight into its rapid decline. First, smallpox could spread rapidly due to the roads' access to the far reaches of the empire. Second, while shuttling resources enabled the Inca to insert their authority when needed, the lack of a constant presence weakened the ties with its captured territories. These weakened ties might explain why the rest of the empire did not rise up against the Spanish once the Inca leadership had fallen despite outnumbering them. In fact, many of the indigenous people participated in the overthrow of the empire.

An example of a topological network analysis can be found in the use of a communication network in the Cappadocian region of present day Turkey. From 1940 $\mathrm{BC}$ to $1740 \mathrm{BC}$, a number of Assyrian merchant colonies thrived there during the Bronze Age. Many of the location of these cities were lost over the subsequent centuries. To rediscover these lost cities, Tobler and Wineberg (1971) used the existence of networks. However, unlike the Inca example where a physical road network was known, they turned to another of form of network, a communication network between the cities, to identify their possible locations. Archaeologists had already uncovered a total of 819 cuneiform tablets referencing 119 cities. Tobler and Wineberg were able to associate the origin of most of the tablets with individual cities. Each of these tablets includes references to other cities. They reasoned that the more times a city was mentioned, the larger or closer that city may be to the tablet’s city of origin. By viewing this "chatter" as a topological arrangement, they were ultimately able to bring in other tools such as the gravity model and trilateration to estimate locations of 62 of the listed cities. 
The type of problems in the Delta requires both physical and topological network analysis. As the solutions are focused on finding particular paths or nodes in the Delta, many of the tools and measurements come from studies identifying network vulnerability. While the context of vulnerability may not necessarily apply to the Delta, finding the vulnerable nodes or paths is associated with their importance.

Vulnerability refers to the loss of connectivity in some manner. Often vulnerability studies involve describing the impact if a node (or edge) was removed by some form of attack, or interdiction. These interdictions can occur randomly as in a natural disaster or deliberately as in a terrorist attack. Although many principles of network vulnerability already existed, this field became particularly active in the wake of terrorist attacks on the World Trade Center and the Pentagon on September 11, 2001, when identifying vulnerable targets in the nation's infrastructure became of primary importance (Grubesic, Matisziw, Murray, and Snediker 2008).

In a physical network analysis, there have been a variety of measures used for gauging vulnerability. Grubesic and Murray (2006) used the Internet backbone companies of WorldCom and ICG to test various interdiction scenarios. Here nodes represented the cities that served as Internet hubs and edges represented the fiber optic lines that connected these cities. Each edge had an attribute associated with bandwidth capacity. Vulnerability was measured by totaling this bandwidth capacity loss for each edge disconnected in the event of an interdiction. Similarly, Kim, Han, and Boyce (2002) looked at the trucking industry. In this case, vulnerability was measured by the additional distance needed for alternative routes taken as key roads were removed by some form of 
interdiction. As added distance equates to additional costs in fuel and time, the shortest route was considered the preferable path. The Delta problem pertaining to drinking water paths also equates distance to additional costs for protection, and therefore, finding the shortest route will also be the goal.

The vulnerability measures for topological network analysis are more varied. Gauging the backup connection readiness to prevent node isolation from the network is one form of measure. Soni and Pirkul (2002) studied providing every node in a telecommunication network with a backup plan for rerouting. Although the study questions its practicality, it does allow one to weigh options. Determining the existence of backup routes will be used to address the Delta problem of stranded islands.

The constraints of limited resources also lead to the need for identifying the critical node for protection. Such is the case with free scale networks which are commonly associated with the hub and spoke networks of the airline or other transportation industries. If the hub is protected, it will prevent the peripheral nodes from being isolated (Barabasi and Albert 1999). Some researchers (Church, Scaparra, and Middleton 2004; Latora and Marchiori 2005) tried to create mathematical models to determine the critical node for specific scenarios/industries. A more universal tool that can help determine the critical node is the binary connectivity matrix (Haggett and Chorley 1969). It is a power algebraic matrix that will calculate all the possible paths between two nodes. In the illustrated example (see Table 2-1), there are five nodes in a network with an accompanying binary connectivity matrix showing all the connections. Matrix1 shows a network distance of one which would be a node's immediate neighbor. 
Table 2-1: Sample network using the binary connectivity matrix

BINARY CONNECTIVTYY MATRICES

\begin{tabular}{|c|c|c|c|c|c|c|}
\hline \multicolumn{7}{|c|}{ To } \\
\hline \multirow{6}{*}{ From } & & A & B & C & D & $\mathrm{E}$ \\
\hline & A & $\hat{0}$ & 1 & 0 & 0 & 0 \\
\hline & $B$ & 1 & 0 & 1 & 1 & 0 \\
\hline & C & 0 & 1 & 0 & 1 & 1 \\
\hline & D & 0 & 1 & 1 & 0 & 1 \\
\hline & $\mathrm{E}$ & 0 & 0 & 1 & 1 & 0 \\
\hline
\end{tabular}

$\begin{array}{ccrrrr}\text { matrix } 2=\text { matrix } & { }^{*} & \text { matrix } 1 & & & \\ \text { A } & \text { A } & \text { B } & \text { C } & \text { D } & \text { E } \\ \text { B } & 1 & 0 & 1 & 1 & 0 \\ \text { C } & 0 & 3 & 1 & 1 & 2 \\ \text { D } & 1 & 1 & 3 & 2 & 1 \\ \text { E } & 1 & 1 & 2 & 3 & 1 \\ & 0 & 2 & 1 & 1 & 2\end{array}$

\begin{tabular}{cccccc}
\multicolumn{2}{r}{ matrix $3=$ matrix $2^{*}$} & matrix 1 & & & \\
& A & B & C & D & E \\
A & 0 & 3 & 1 & 1 & 2 \\
B & 3 & 2 & 6 & 6 & 2 \\
C & 1 & 6 & 4 & 5 & 5 \\
D & 1 & 6 & 5 & 4 & 5 \\
E & 2 & 2 & 5 & 5 & 2
\end{tabular}

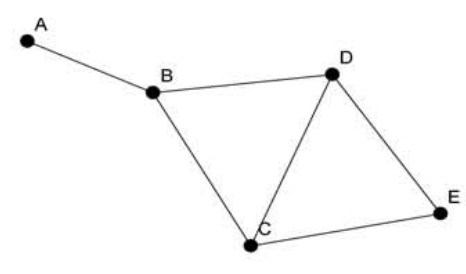

SUMMARY MATRICES

\begin{tabular}{|c|c|c|c|c|c|c|}
\hline \multicolumn{7}{|c|}{ sum $1=$ matrix 1} \\
\hline \multirow{6}{*}{ From } & & A & B & C & D & $\mathrm{E}$ \\
\hline & A & 0 & 1 & 0 & 0 & 0 \\
\hline & B & 1 & 0 & 1 & 1 & 0 \\
\hline & C & 0 & 1 & 0 & 1 & 1 \\
\hline & D & 0 & 1 & 1 & 0 & 1 \\
\hline & $\mathrm{E}$ & 0 & 0 & 1 & 1 & 0 \\
\hline
\end{tabular}

\begin{tabular}{cccccc}
\multicolumn{2}{c}{ sum2=sum $1+$ matrix 2} & & & \\
A & A & B & C & D & E \\
B & 1 & 1 & 1 & 1 & 0 \\
C & 1 & 3 & 2 & 2 & 2 \\
D & 1 & 2 & 3 & 3 & 2 \\
E & 1 & 2 & 3 & 3 & 2 \\
& 0 & 2 & 2 & 2 & 2
\end{tabular}

\begin{tabular}{|c|c|c|c|c|c|c|}
\hline \multicolumn{7}{|c|}{ sum $3=$ sum $2+$ matrix 3} \\
\hline & A & B & C & D & $E$ & From - Accessibility Summary \\
\hline A & 1 & 4 & 2 & 2 & 2 & 11 \\
\hline B & 4 & 5 & 8 & 8 & 4 & 29 \\
\hline c & 2 & 8 & 7 & 8 & 7 & 32 \\
\hline D & 2 & 8 & 8 & 7 & 7 & 32 \\
\hline $\mathrm{E}$ & 2 & 4 & 7 & 7 & 4 & 24 \\
\hline \multicolumn{7}{|c|}{ To - Accessibility Summary } \\
\hline & 11 & 29 & 32 & 32 & 24 & \\
\hline
\end{tabular}


Matrix2 shows a network distance of two which would be a node reached in two "jumps." A completed matrix would connect the furthest "from" and "to" nodes, in this case nodes A and E. The number of jumps needed to complete the matrix is also known as the network diameter. Because this takes three "jumps," the network diameter is considered three. Separate summary matrices were kept to total all of the possible connections. The From - Accessibility Summary shows the highest betweeness "from" nodes to be C and D. The To - Accessibility Summary shows the highest betweeness "to" nodes also to be C and D. As the binary connectivity matrix is a way to determine these busiest nodes, this is the tool that will be used to determine the optimal monitoring sites for the delta smelt. 


\section{Chapter 3}

\section{Network Problem Solving Demonstration}

As previously stated, the three problems of optimal monitoring sites, stranded islands, and drinking water paths will be addressed to examine the effectiveness of networks for problem solving. As the purpose is to explore the possibilities from a strictly network point of view, assumptions will be made to simplify the process. Before considering any kind of implementation, the results require further refinement by including additional factors and details.

In setting the study area, one of the keys was deciding the scale to make the best use of the networks. For example, if a small scale were maintained where the entire Delta appeared simply as a valuable node on a large network, the problem solving capabilities would be severely limited especially for taking a specific action for a specific location within the Delta. The level at which these large networks can be seen as individual islands and waterways was selected as the ideal scale. At this scale, existing networks tools and measures were able to take advantage of what initially appeared as a confusing maze. Within the legal Delta boundaries, the larger 42 Delta islands (Delta Islands) were chosen for the study area (see Figure 3-1). The source was a map based on a major study on subsidence in the Delta (Mount and Twiss 2005) and represented the best combination of distinction and details of the islands available for this thesis. The islands were digitized by georeferencing the map contained in the report using ESRI ArcGIS, which is a kind of geographic information systems (GIS) software. 


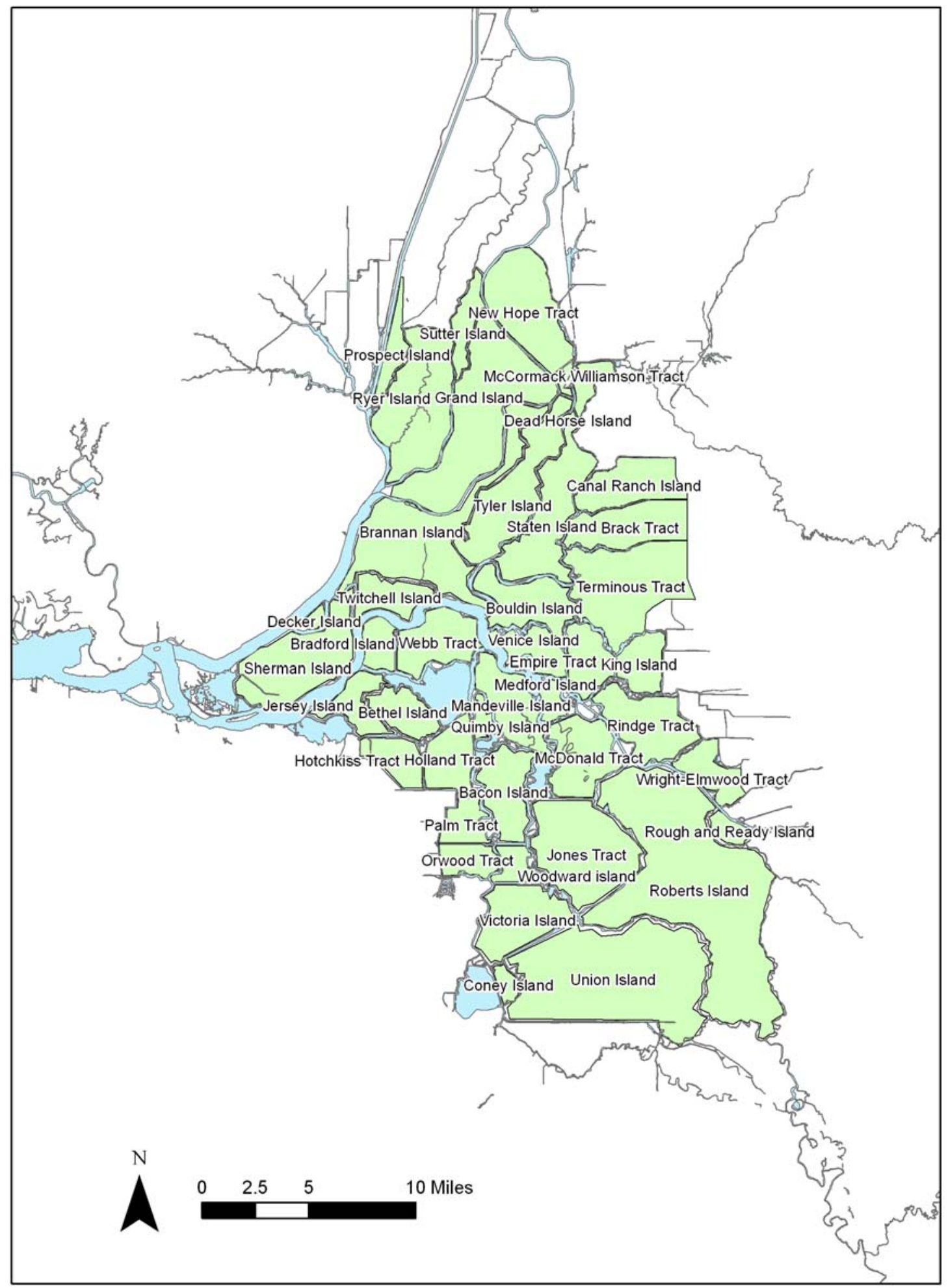

Figure 3-1: The Delta islands and waterways used for the study area. 


\section{Example 1: Stranded Islands}

To approach the problem of stranded islands, the focus will be on the roads which are a vital transportation network for California. The study area contained state highways 4, 12, and 160 as well as many smaller roads. For this experiment, the definition for identifying a potential stranded island was an island that did not have road access to the mainland if any one neighboring island were flooded. Therefore, a safe island would generally be any that either had a direct route to the mainland or at least two indirect routes regardless of which neighboring island was flooded. Among the assumptions, binary flooding was a key concept, where the state of an island was considered flooded or not. This was assumed because with the deep subsidence in each of the islands and the force of water, there is nothing to stop an entire island from flooding once a levee fails. In refining the network, those islands connected only by ferry and not by roads were excluded. While ferries may be able to support sparsely populated islands, they would not be adequate for future urbanization. Of the 42 islands, only 6 had ferry connections: Bradford Island, Webb Tract, Quimby Island, Medford Island, Woodward Island and Venice Island (California Department of Water Resources 2010). For the remaining islands, roads that connected them to a neighboring island or the mainland were examined. Because of the binary flooding nature, only one road was needed per connection. If there were two roads from one island that both led to the same neighboring island, then that served as one connection. The initial road dataset was taken from the U.S. Geological Survey (USGS). The initial plan was to use this dataset in the GIS as a means to detect interisland connections programmatically. However, there were 
overlay problems where the road would display in the water which could be explained by road dataset or island digitizing accuracy. The close proximity of the islands and the fact that a great many of the roads followed the perimeter of an island exacerbated the accuracy issue. This created difficulty in determining island connections through automated GIS means. Because of this difficulty, the decision was made not to use the USGS dataset and instead use Google Maps' “Map” view as a visual reference to tabulate the road connections. Bing/Yahoo maps were considered but did not show as much road detail in the Delta Islands as Google Maps. The assumption of binary flooding enabled a straightforward visual approach to determining whether each island had more than one path to the mainland. For two islands, McDonald Tract and Dead Horse Island, the DWR's Delta Atlas (California Department of Water Resources 2010) indicated road connections but the "Map” view displayed no roads. For these islands, Google Maps' "Satellite" view was used to visually check for road connections. Both islands were confirmed visually via aerial photos to have road connections.

To prevent the map from being too convoluted with the roads, a GIS tool from ET GeoWizards was used to generate a centroid point for each island. Connecting the centroids made visualizing the island connections much simpler (see Figure 3-2). 

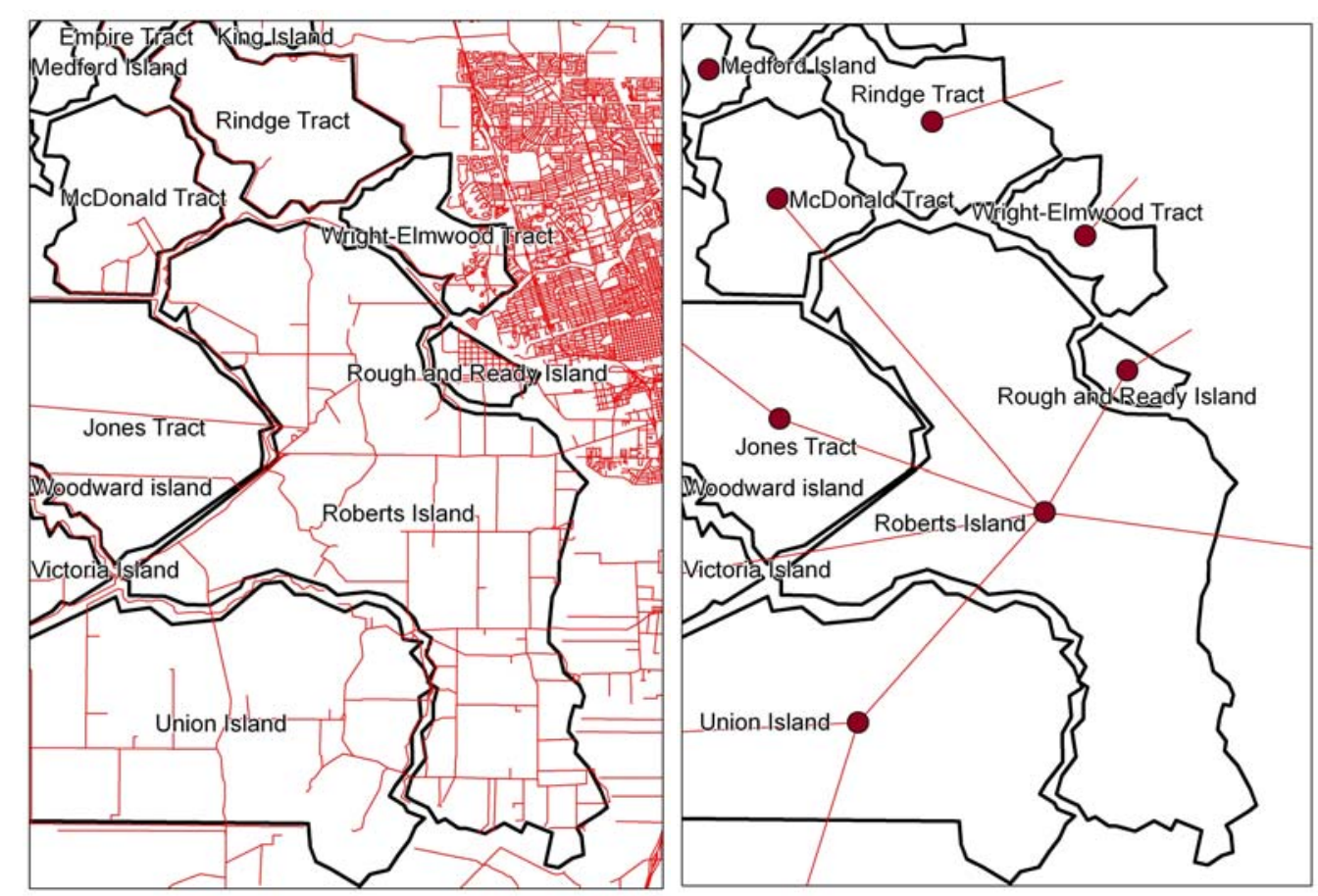

Figure 3-2: Converting from roads to centroids connection display.

The results of the visual tabulation were displayed on a map using GIS software.

A total of 11 islands were deemed vulnerable to being stranded. They were comprised of the following: Empire Tract, Palm Tract, Twitchell Island, Dead Horse Island, McDonald Tract, Jones Tract, Coney Island, Bacon Island, Mandeville Island, Jersey Island, and Bethel Island (see Figure 3-3). Defining stranded as not having a route to the mainland if a particular island on the road network were to flood means that an island such as Dead Horse Island would be considered stranded if State Island were to flood. This is different for neighboring Tyler Island if State Island were to flood. In this case, Tyler Island would still have a variety of options to get to the mainland. Residents could travel to Brannan Island and get to the mainland from there or they could proceed to 


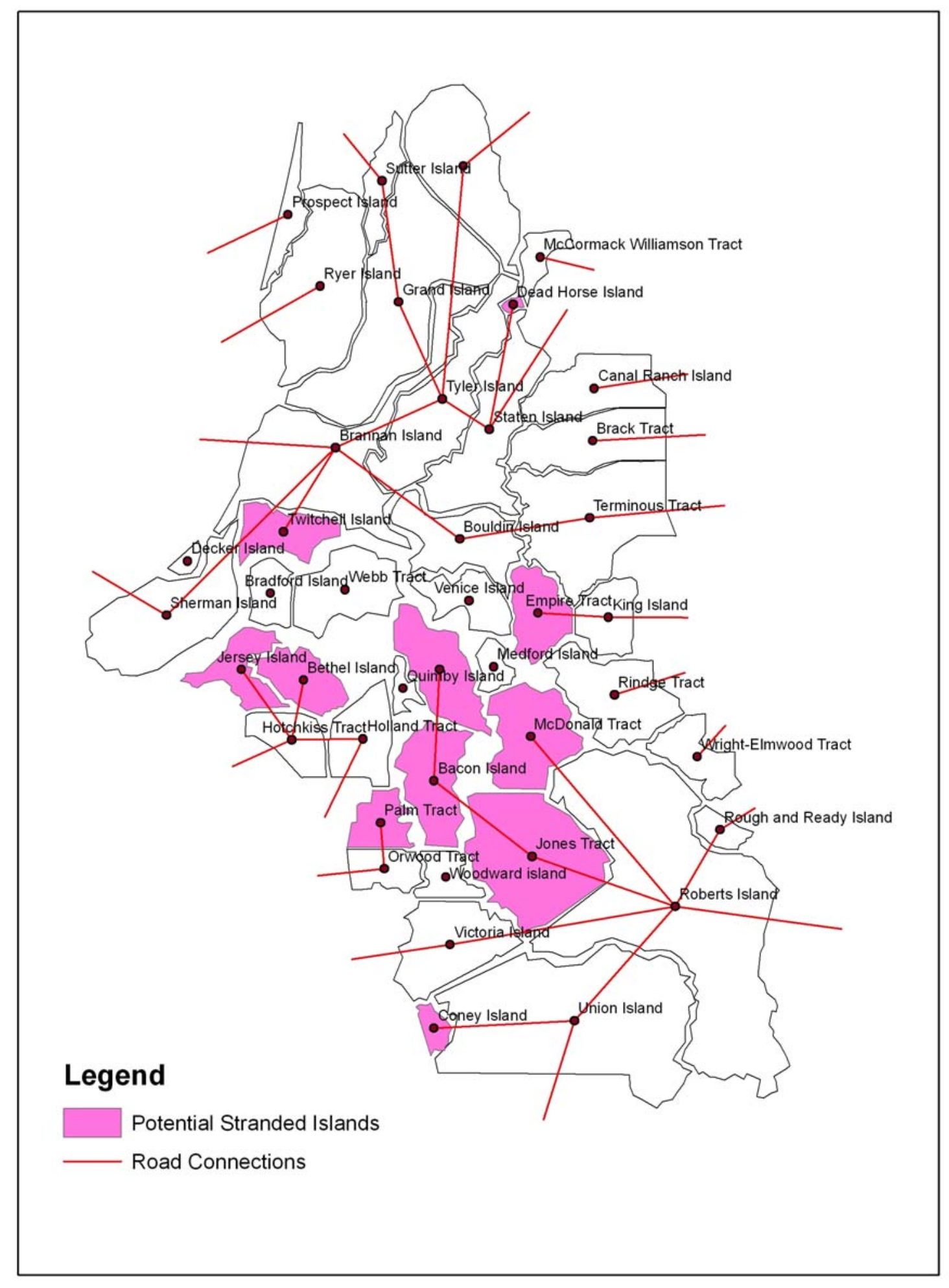

Figure 3-3: Potential stranded islands. 
Sherman Island before exiting. Tyler Island residents would also have the option to drive via Grand Island and Sutter Island to get to the mainland or drive via New Hope Tract. In most cases, the flooding of an immediate connected island would result in the stranding. For example, flooding Roberts Island in the southern end of the Delta would strand both McDonald Tract and Jones Tract. Although Jones Tract residents could escape to Bacon Island, they could not reach the mainland. Bacon Island was considered more vulnerable because it depended on two islands for exit routes. If Jones Tract were flooded, Bacon Island residents could not reach the mainland. However, if Roberts Island were flooded, they also could not reach the mainland. Mandeville Island is the most vulnerable because it depends on three islands not flooding: Bacon Island, Jones Tract, and Roberts Island.

The results suggest a choice to restrict urbanization on these remaining islands or to expand the road system. If the road system is expanded then the roads should expand the connections. Each of the potential stranded islands was explored for possible solutions (see Table 3-1) that show possible connection to an island or direct connection to mainland. For example, in the case of an island stranding scenario of Empire Tract, an alternate route can be constructed to Bouldin Island. From here, residents would have a variety of options to reach the mainland. Alternate road construction to Terminous Tract or Rindge Tract would yield similar options. In the case of Mandeville Island, the options are not as clear because at least two roads would need to be constructed. 
The results are important because they represent a new guideline for urbanization. Whereas currently urbanization can continue unchecked with only vague assurances of safety, requiring two paths to the mainland is something concrete.

Table 3-1: Summary of potential stranded islands and possible solutions.

\begin{tabular}{|l|l|}
\hline Potential Stranded Islands & \multicolumn{1}{|c|}{ Possible Road Connection } \\
\hline Empire Tract & Bouldin Island, Terminous Tract, Rindge Tract \\
\hline Palm Tract & Holland Tract, Bacon Island, mainland \\
\hline Twitchell Island & Sherman Island \\
\hline Dead Horse Island & Tyler Island, Williamson Tract \\
\hline McDonald Tract & Rindge Tract \\
\hline Jones Tract & Victoria Island \\
\hline Coney Island & Victoria Island, mainland \\
\hline Bacon Island & Palm Tract, Holland Tract \\
\hline Mandeville Island & $* *$ requires 2 additional roads** \\
\hline Jersey Island & Sherman Island, mainland \\
\hline Bethel Island & Holland Tract \\
\hline & \\
\hline
\end{tabular}




\section{Example 2: Optimal Monitoring Sites}

In approaching the optimal monitoring sites problem, the delta smelt network was used. In the study area, the delta smelt network was portrayed as the waterways between the Delta Islands for which a number of assumptions were made for simplification.

Although the smelt is present in the study area in summer and winter, this study focused on their summer journey when water pumping demand is at its highest and the smelt are scattered. In addition to the danger of being entrained by the massive Tracy and Banks Pumps at the southern end of the Delta, the intake strength of the two pumps is so powerful that they can reverse the direction of some of the smaller streams and tributaries which confuse the smelt's sense of direction. Because of this, any waterway was considered eligible for this study.

Using ESRI ArcGIS software, the delta smelt network was constructed with the waterways as segments and the intersections as nodes (see Figure 3-4). Considering the number of paths, it seemed most efficient to target the intersections as they can increase the possibility of detection. First, a line shapefile between and around the islands was created. A choice of more than one direction determined the definition of an intersection point. All line segments were "snapped" to these intersection vertex points. Next the network was generated in the GIS with the ESRI Network Analyst extension. By doing so, each intersection became a node and was assigned a number from 1 to 73 . 


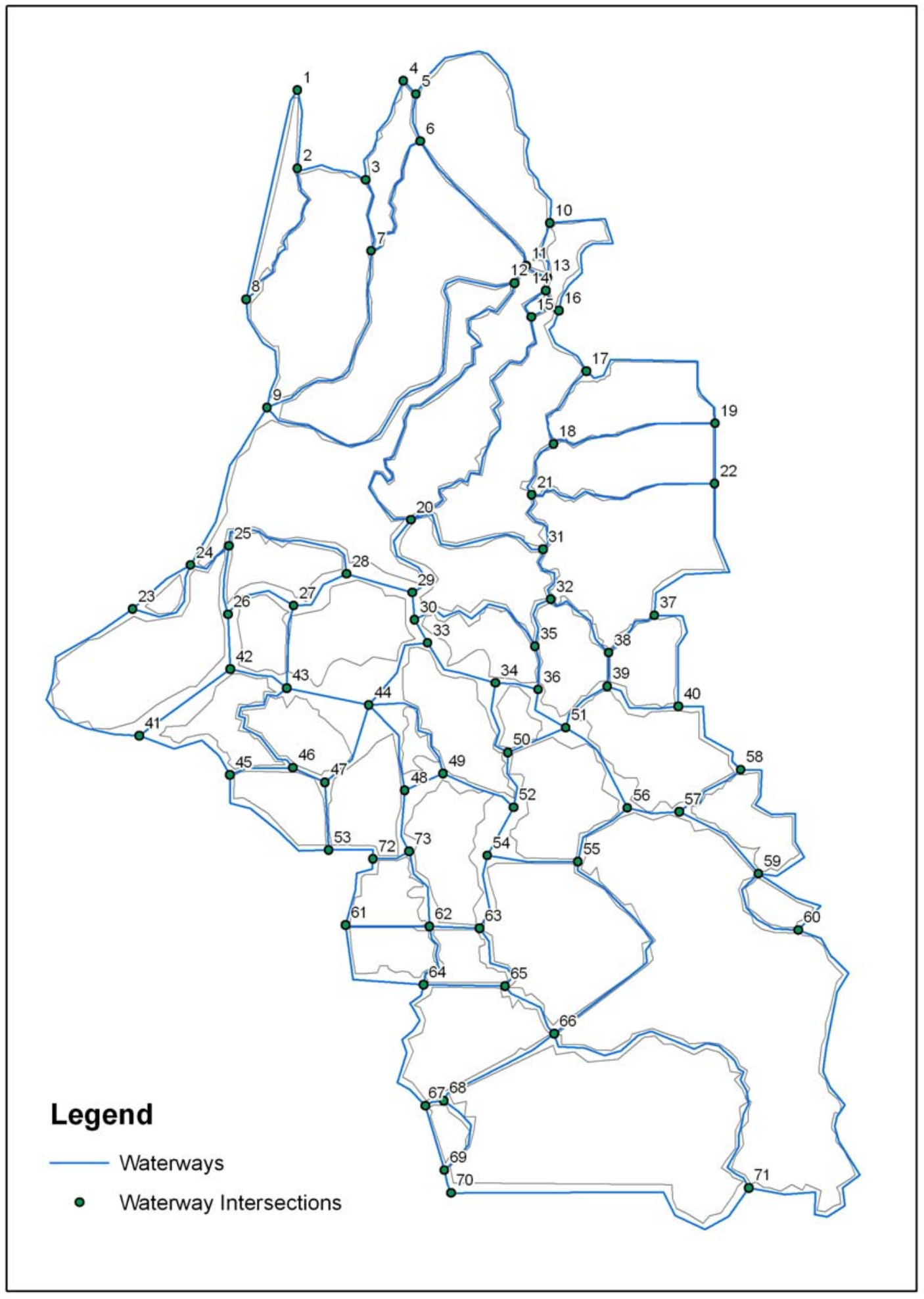

Figure 3-4: Constructed delta smelt network. 
To determine the optimal monitoring sites, a binary connectivity matrix of 73 rows and 73 columns was made using a Microsoft Excel spreadsheet. Because of the sheer size, a separate spreadsheet was kept for the summary matrices. As in the binary connectivity matrix sample, matrix1 comprised of 1's and 0's. For example, for intersection row and column 1, a " 1 " would occupy all the accessibility connections for intersections 2 and 8 . The rest of column and row 1 had a " 0 ." This process was carried out for the remaining rows and columns out to 73. Built-in Excel functions were then used to define matrix 1 and apply the definition to the formulas listed for matrix 2 and sum 1 and onward until the network diameter of 13 was met. As described earlier, the network diameter is the number of power matrix iterations reached when the furthest nodes on the network finally connect.

The binary connectivity matrix revealed the most accessible to/from nodes. Although the ranking order for each was different, they were the same numbers (see Tables 3-2 and 3-3). In order they were 33, 43, 44, 47, 48, 49, 61, 62, 64, and 73. As such, there could have been as many as twenty potential sites but the result came out to be 10. All were concentrated in the western Delta Islands (see Figure 3-5).

Table 3-2: Top ten "From" connections.

\begin{tabular}{|c|c|}
\hline Intersection & Total Connections \\
\hline 44 & 12687291 \\
\hline 43 & 9454739 \\
\hline 62 & 9257338 \\
\hline 64 & 8811524 \\
\hline
\end{tabular}




\begin{tabular}{|c|c|}
\hline 48 & 8660912 \\
\hline 49 & 8289813 \\
\hline 47 & 7728569 \\
\hline 61 & 7488398 \\
\hline 73 & 7428306 \\
\hline 33 & 7194341 \\
\hline
\end{tabular}

Table 3-3: Top ten "To" connections.

\begin{tabular}{|c|c|}
\hline Intersection & Total Connections \\
\hline 44 & 13562401 \\
\hline 43 & 9887268 \\
\hline 62 & 9383445 \\
\hline 48 & 9133735 \\
\hline 64 & 8885146 \\
\hline 49 & 8767205 \\
\hline 33 & 8351191 \\
\hline 47 & 8150876 \\
\hline 73 & 7637278 \\
\hline 61 & 7578249 \\
\hline
\end{tabular}




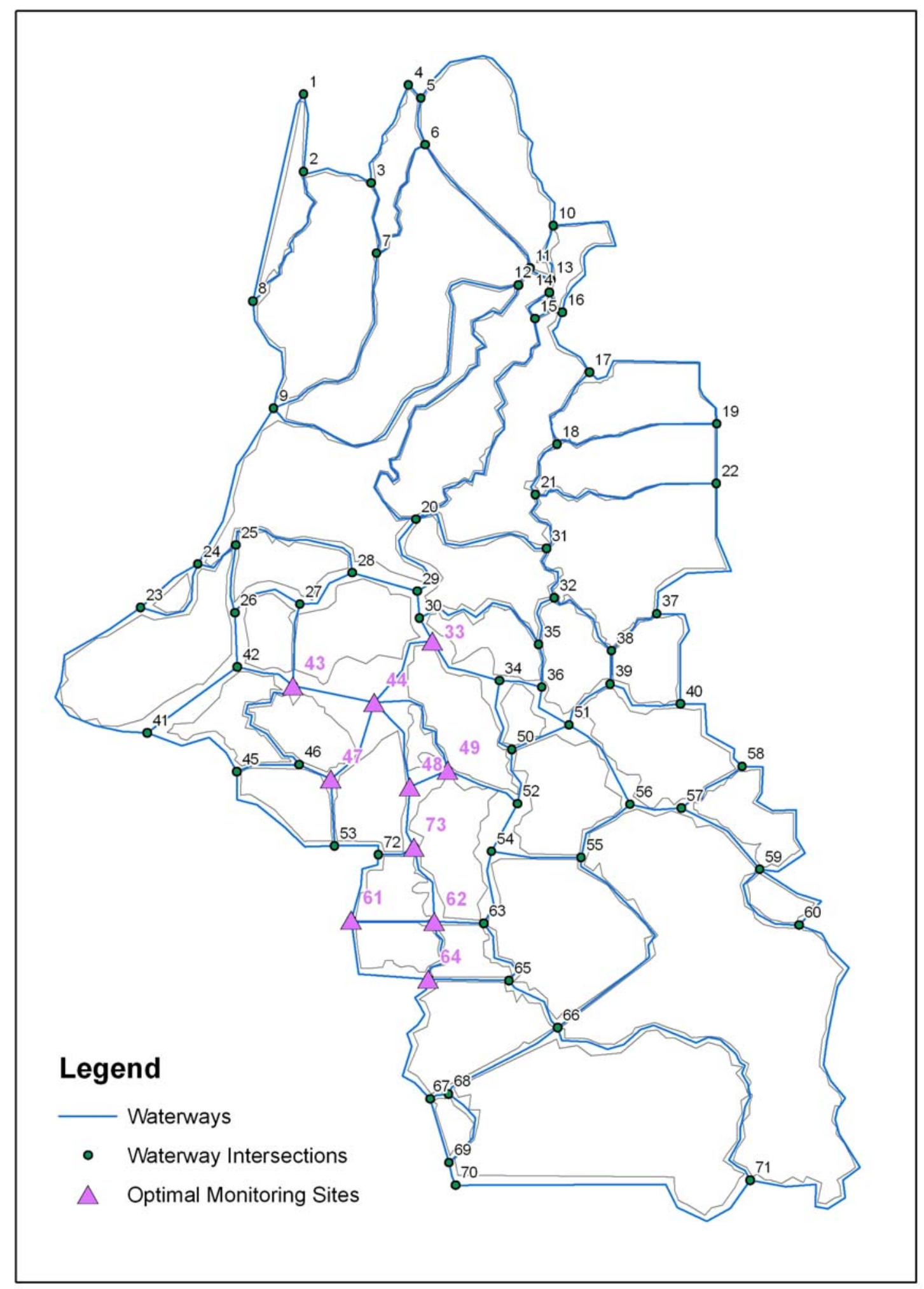

Figure 3-5: Optimal monitoring sites for delta smelt. 
The "busiest" sites determined by the results differ greatly from the current locations of the survey sites used by the Department of Fish and Game (see Figure 3-6). Although these sites have a dual purpose of determining the population's health and to help prevent entrainment, it was surprising to see none of the Department of Fish and Game's sites appeared to be placed in an intersection. To compensate for some possible inaccuracies in location, a one mile buffer was created around the top ten monitoring sites. Using the ArcMap Intersect tool, stations within this buffer were identified. Still only three of their sites were within the 1 mile buffers.

The results are important because they promote coexistence and the better use of limited resources. Monitoring frequency can be increased with fewer sites, and the number of days that the pumps remain idle can be minimized. Rather than choosing one over the other in terms of the delta smelt or drinking water for people, the emphasis is on minimizing the negative impact to each other. 


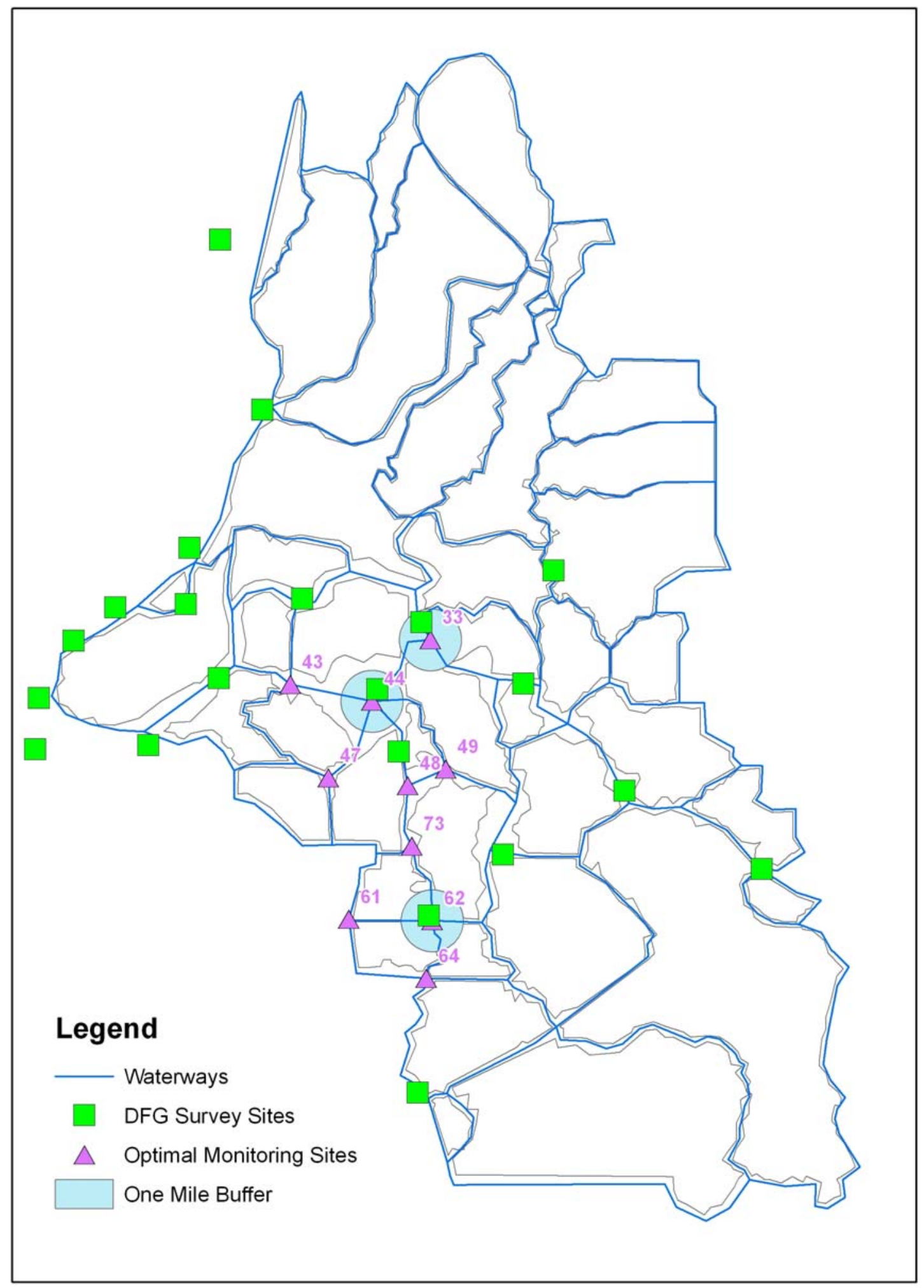

Figure 3-6: Comparing proximity to current Department of Fish and Game's survey sites. 


\section{Example 3: Drinking Water Paths}

The approach for the drinking water paths problem focused on the water conveyance network of the CVP and SWP from the Sacramento and San Joaquin Rivers to the Banks and Tracy Pumps at the southern end of the Delta. Like the smelt network, the water conveyance network also was portrayed in the study area as any of the waterways between the Delta Islands. In fact, much time was saved by using the same digitized waterways and network nodes created for the delta smelt network

The main assumption here was a through-Delta solution and that would involve a tunnel or a fortified aqueduct with adequate capacity. ESRI's Network Analyst was used to calculate the shortest path for each of the rivers to reach the Tracy and Banks pumps (see Figure 3-7). In selecting the starting location, two sites were chosen: one from the Sacramento River and one from the San Joaquin River. The Sacramento site (point A) was located at a northern point between Sutter Tract and New Hope Island. The San Joaquin site (point B) was at the intersection between the Old and Middle tributaries. The destination site (point C) represented the Banks and Tracy Pumps. Network Analyst ran for each route for a total of two times. The results showed total lengths of 235,779 feet for the Sacramento Route and 80,561 feet for the San Joaquin Route.

The network approach of finding the shortest routes seeks to make the best use of limited resources by identifying the shortest routes from the river sources to the southern pumps. The combined length of the two routes was 316,340 feet (or 59.91 miles). The current policy is to maintain all the levees, a distance roughly equivalent to the perimeter 


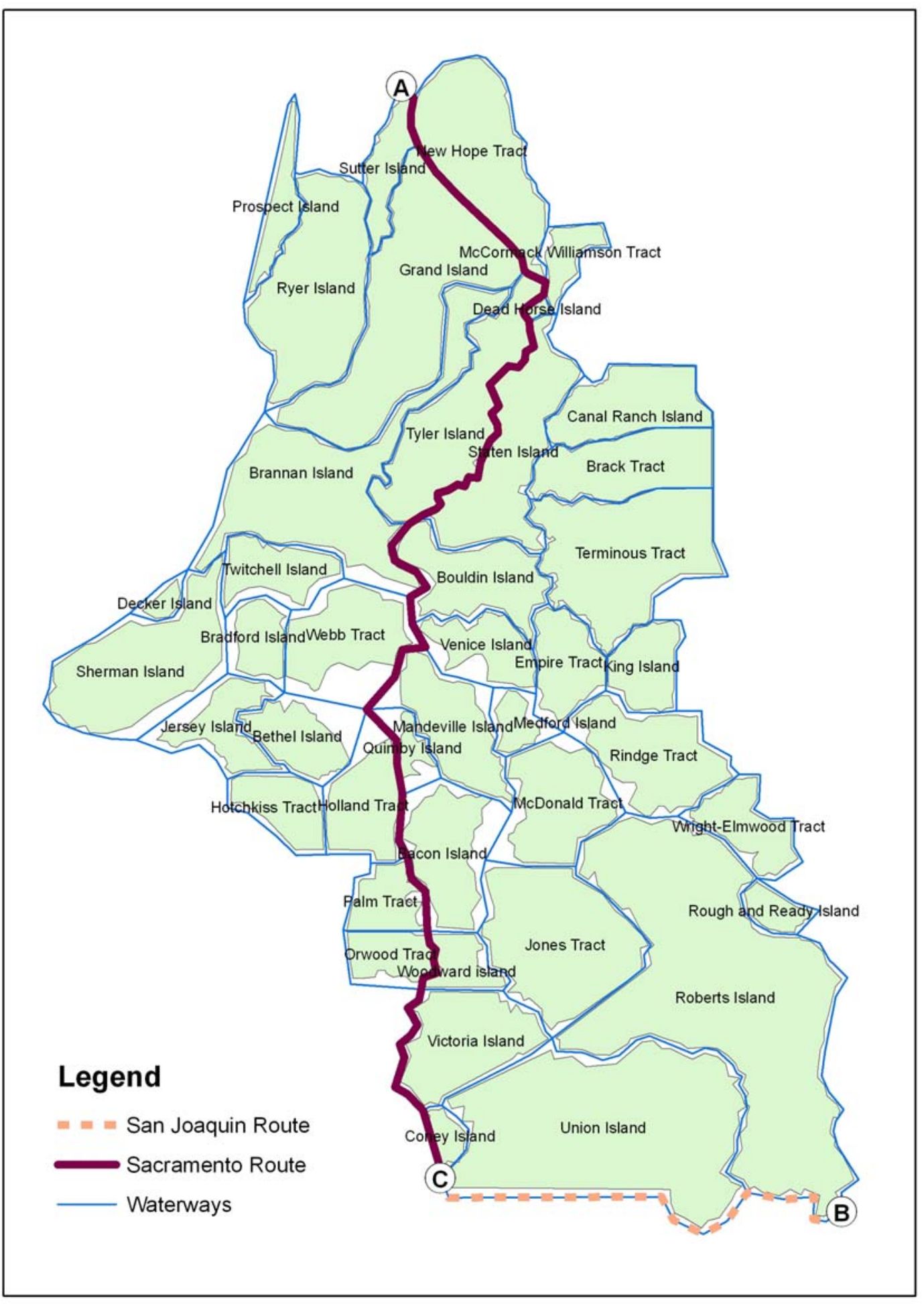

Figure 3-7: Shortest drinking water paths. 
of all 42 Delta Islands. This was calculated to approximately 3,293,426 feet (or 623.75 miles) which was done by taking the perimeter of all the islands stored in a personal geodatabase. Although some islands may not be as vital in protecting the drinking water, the fact that the two routes represent a $90 \%$ decrease in the length that needs to be maintained is significant. Considering the state of the levees and the lack of funding, this might mean the difference in having adequate protection and maintenance of the drinking water. Whereas in many cases having many alternate routes is preferred, the waterway redundancy is not only costly but unsafe when protection of the drinking water is reliant on the length of island levees. 


\section{Chapter 4}

\section{Conclusion}

The objective of this thesis was to explore the problem-solving implications of networks in the Delta. In each of the examples for stranded islands, optimal monitoring sites, and drinking water paths, the results revealed an underlying pattern not readily apparent from viewing the confused maze of waterways and islands.

An important finding is that networks offer a possible solution framework for a process that currently has no framework to manage the Delta's complexity. These results do not represent the end but the starting point. The assumptions used were very simple. Most likely the specific locations offered in the solutions will change as they are refined by incorporating other details and factors that match actual conditions on the ground. For the stranded islands example, this could mean reviewing the urbanization plans for the islands that have been identified in the stranded islands' example. Road construction suitability studies can be conducted for future island connections. For the drinking water paths’ example, issues such as capacity and cost of levee fortification and/or tunnel construction can be estimated. For the optimal monitoring sites' example, other factors such as temperature, flow speed, and food source need to be weighed.

Study expansions are also possible. In the case of the optimal monitoring sites, if the refined sites prove successful, the most frequented paths for entrainment can be blocked with fish screens or ladders. Furthermore, these networks addressed problems separately but many of the networks overlap. The waterways formed a network for both the water conveyance and the delta smelt. The waterways also formed the barrier for the 
road network connecting the various islands. As such, the solutions could overlap. For example, a future study might involve investigating the number of many days of idle pumping for water conveyance that would be reduced as a result of the optimized monitoring sites for smelt. Another future study might entail calculating the savings in terms of levee fortification costs by limiting urbanization on certain islands. These funds could be redirected towards fortification plans outlined in the drinking water paths' example.

This thesis shows that networks can be a versatile tool for understanding many societal questions. With clashes between humans and nature becoming more prevalent, this tool could be used to determine ways for coexistence. In addition, networks have been demonstrated to be a vehicle for compromise. By setting guidelines and optimizing the use of limited resources, the examples within this thesis have established the kind of goals that enable stakeholders to come together. This approach contributes to the idea that the Delta is not a battleground to be fought over, but a valuable resource that can be shared. 


\section{References}

Barabasi, A., \& Albert, R. (1999). Emergence of Scaling in Random Networks. Science, 286, 509-512.

Bennett, W. (2005). Critical Assessment of the Delta Smelt Population in the San Francisco Estuary, California. San Francisco Estuary and Watershed Science, 3(2).

Buchanan, W. (2010, June 30). Schwarzenegger Moves to Pull Water Measure. The San Francisco Chronicle. Retrieved February, 2011, from http://articles.sfgate.com/2010-06-30/news/21931499_1_water-bond-voters-billion$\underline{\text { deficit }}$

California Department of Fish and Game. (2009). Salvage Monitoring. Retrieved September, 2009, from http://www.dfg.ca.gov/delta/apps/salvage/Default.aspx

California Department of Fish and Game. (2009). 20mm Survey. Retrieved September, 2009, from http://www.dfg.ca.gov/delta/projects.asp?ProjectID=20mm

California Department of Water Resources. (2005). Flood Warnings: Responding to California's Flood Crisis. Sacramento: Author.

California Department of Water Resources. (2007). Bay-Delta Levees. Retrieved December, 2007, from http://www.dfm.water.ca.gov/dsmo/levees/components.html

California Department of Water Resources. (2009). 2009 Comprehensive Water Package. Retrieved February, 2011, from http://www.gov38.ca.gov/images/page/water/HistoricWaterPackage.pdf

California Department of Water Resources. (2010). Delta Atlas. Retrieved October, 2010, from http://baydeltaoffice.water.ca.gov/DeltaAtlas/index.cfm

California Energy Commission. (2008). The California Agriculture Economy. Retrieved February, 2011, from http://www.energy.ca.gov/research/iaw/industry/agri.html

Church, R.L., Scaparra, M.P., \& Middleton, R.S. (2004). Identifying Critical Infrastructure: The Median and Covering Facility Interdiction Problems. Annals of the Association of American Geographers, 94(3), 491-502.

Dreifus, C. (2006, April 18). Giving Sacramento Good Reason to Have New Orleans on Its Mind. The New York Times. Retrieved February, 2011, from http://www.nytimes.com/2006/04/18/science/18conv.html 
Gladwell, M. (2005). Blink: The Power of Thinking Without Thinking. New York: Back Bay Books / Little, Brown and Company.

Grubesic, T.H., Matisziw, T.C., Murray, A.T., \& Snediker, D. (2008). Comparative Approaches for Assessing Network Vulnerability. International Regional Science Review, 31(1), 88-112.

Grubesic, T.H., \& Murray, A.T. (2006). Vital Nodes, Interconnected Infrastructures, and the Geographies of Network Survivability. Annals of the Association of American Geographers, 96(1), 64-83.

Haggett, P., \& Chorley, R. J. (1969). Network Analysis in Geography. London: Edward Arnold Ltd.

Hundley, N. (2001). The Great Thirst. Berkeley, CA: University of California Press.

Kim, T.J., Ham. H, \& Boyce, D.E. (2002). Economic Impacts of Transportation Network Changes: Implementation of a Combined Transportation Network and Input-Output Model. Papers in Regional Science, 81, 223-246.

Latora, V., \& Marchiori, M. (2005). Vulnerability and Protection of Infrastructure Networks. Physical Review E, 71(015103), 1-4.

Lund, J., Hanak, E., Fleenor, W., Howitt, R., Mount, J., \& Moyle, P. (2007). Envisioning Futures for the Sacramento-San Joaquin Delta. San Francisco: Public Policy Institute of California.

Mount, J., \& Twiss, R. (2005). Subsidence, Sea Level Rise, and Seismicity in the Sacramento-San Joaquin Delta. San Francisco Estuary and Watershed Science, 3(1).

Smith, M. (2005). Networks, Territories, and the Cartography of Ancient States. Annals of the Association of American Geographers, 95(4), 832-849.

Soni, S., \& Pirkul, H. (2002). Design of Survivable Networks with Connectivity Requirements. Telecommunication Systems, 20, 133-149.

Simitian, J. (2009). Simitian Delta/Water Bill Approved by Legislature Goes to Governor for Signature [Press Release]. Retrieved February, 2011, from http://www.senatorsimitian.com/entry/simitian_delta_water_bill_approved_by_legi slature_goes_to_governor_for_sign/

Termorshuizen, J.W., Opdam, J., \& van den Brink, A. (2007). Incorporating Ecological Sustainability into Landscape Planning. Landscape and Urban Planning, 374-384. 
Tobler, W., \& Wineberg, S. (1971). A Cappadocian Speculation. Nature, 231, 39-41.

Tolan, S. (2009). Waterworld. California. Retrieved February, 2011, from http://alumni.berkeley.edu/news/california-magazine/winter-2009-foodthought/waterworld

U.S. Fish and Wildlife Service, Pacific Southwest Region. (2010). Service Finds Uplisting of Delta Smelt from Threatened to Endangered Under Endangered Species Act "Warranted but Precluded" [Press Release]. Retrieved February, 2011, from http://www.fws.gov/cno/press/release.cfm?rid=69

van Heerden, I., \& Bryan, M. (2006). The Storm: What Went Wrong and Why During Hurricane Katrina. New York: Viking / Penguin Group.

Watts, D.J. (2003). Six Degrees: The Science of a Connected Age. New York: W. W. Norton \& Company. 